\title{
MENINGKATKAN KUALITAS PELAYANAN PERPUSTAKAAN TERHADAP GENERASI DIGITAL NATIVE
}

\author{
Eko Sulistyo \\ Institut Seni Indonesia (ISI) Surakarta \\ ekoalaska@gmail.com
}

\begin{abstract}
Improving the Quality of Library Services for Digital Native Generations. The generation of Digital Natives, the younger generation born and living in the internet era, tends to use the internet in their daily lives. They are very master of this and of course require librarians to be able to provide access based communication technology. To improve service quality in addition to facilities and communication technology, libraries must provide collections that can be accessed through the internet, so that they can be read anytime and anywhere, including E-Book, E-Paper and E-Journal. Primarily is the collection of E-Journal.
\end{abstract}

Keywords: Service Quality, Digital Native, Service Paradigm

\begin{abstract}
Abstrak
Meningkatkan Kualitas Pelayanan Perpustakaan Terhadap Generasi Digital Native. Generasi Digital Natives, yaitu generasi muda yang lahir dan hidup pada era internet cenderung menggunakan dunia internet dalam kehidupan sehari-hari. Mereka sangat menguasai akan hal ini dan tentunya menuntut pustakawan mampu menyediakan akses berbasis teknologi komunikasi tersebut. Untuk meningkatkan kualitas pelayanan
\end{abstract}


selain fasiltas dan teknologi komunikasi, perpustakaan harus menyediakn koleksi yang sudah bisa diakses melalui internet, sehingga bisa dibaca kapan saja dan dimana saja, antara lain yaitu E-Book, E-Paper dan E-Journal.Utamanya adalah koleksi E-Journal.

Kata Kunci : Kualitas Pelayanan, Digital Native, Paradigma Pelayanan

\section{A. Pendahuluan}

Perguruan Tinggi memiliki peranan yang sangat besar dalam peningkatan sumberdaya manusia yang unggul, mampu bersaing dalam bidangnya.Perguruan Tinggi bertugas menghasilkan lulusan-lulusan yang berkualitas. Proses belajar dan mengajar saja tidak cukup tetapi perlu didukung dengan fasilitas-fasilitas penunjang lainnya terutama perpustakaan. Karena perpustakaan adalah tempat dimana masyarakat, pelajar, dan mahasiswa dapat memperoleh informasi dan belajar mandiri guna untuk meningkatkan kualitasnya.Sebagai pusat informasi, perpustakaan tidak hanya sebatas gedung dan buku.Perpustakaan yang modern memiliki tugas dan fungsi untuk mencari, mengumpulkan, mengorganisasikan, mendokumentasikan dan menyajikan informasi kepada pengguna baik dalam bentuk cetakan maupun dalam bentuk elektronik. ${ }^{1}$

Di era teknologi informasi sekarang ini telah memberikan peluang besar bagi perpustakaan untuk meningkatkan layanan yang telah ada.Layanan yang cepat, tepat dan akurat menjadi daya tarik bagi pengguna perpustakaan, sehingga setiap perpustakaan harus berusaha memberikan layanan terbaiknya. Sejalan dengan UU Nomor 43 Tahun 2007 Tentang layanan perpustakaan Pasal 14 ayat 3 yang menyatakan bahwa setiap perpustakaan mengembangkan layanan perpustakaan sesuai dengan kemajuan

${ }^{1}$ Yulia Nurendah, "Analisis Pengaruh Kualitas PelayananPerpustakaan Terhadap Kepuasan danHubungannya dengan Loyalitas Mahasiswa", JIMKES Jurnal Ilmiah Manajemen Kesatuan Vol. 1 No. 1, 2013. Hal. 93-94. 
teknologi informasi dan komunikasi (Indonesia, 2009:21). Perkembangan layanan ini dilakukan agar layanan perpustakaan dapat diterima dan memuaskan harapan pemustaka. Perpustakaan sebagai wadah informasi dan pendistribusian informasi, harus siap siaga membantu pemustaka untuk mendapatkan informasi yang dibutuhkan. ${ }^{2}$

Perpustakaan dapat diartikan sebagai pelayanan.Semua aktivitas yang dilakukan dalam perpustakaan berbentuk pelayanan. Kepuasan pelanggan (anggota) menjadi salah satu tujuan pelayanan suatu perpustakaan.Untuk mencapai tujuan pelayanan yang berkualitas, perpustakaan dituntut untuk memenuhi kebutuhan stakeholdernya. Tidak saja terpenuhinya sumber-sumber informasi tetapi perlu juga diperhatikan fasilitasfasilitas fisik, kualitas pelayanan, dan teknologi yang dapat membantu proses pelayanan sehingga tercapainya kepuasan pemakai. ${ }^{3}$

Kualitas pelayanan merupakan hal yang harus ada didalam perpustakaan umum dengan adanya kualitas maka pemustaka akan merasa diperhatikan dan akan sering berkunjung didalam perpustakaan umum. Pada dasarnya kualitas menurut Goetsh dan Davis dalam Arief (2007: 177) kualitas merupakan pemenuhan suatu harapan akan sesuatu yang berhubungan dengan produk, jasa, ataupun manusia, dapat dijelaskan bahwa pelayanan yang berkualitas menurut Tri Novianti (2015) dalam perpustakaan digunakan untuk mengukur seberapa baik tingkat layanan yang telah diberikan mampu memenuhi keinginan ataupun harapan pemustaka. Dengan adanya kualitas pelayanan didalam perpustakaan umum hal tersebut juga akan menumbuhkan suatu kepuasan pada pemustaka. ${ }^{4}$

Perkembangan teknologi informasi dalam sepuluh tahun terakhir sangat mencengangkan terutama dengan hadirnya

${ }^{2}$ Andi Pandita, "Pengaruh Pelayanan Terhadap Kepuasan Pemustaka Di UPT Perpustakaan Universitas Negeri Makasar". Skripsi. Fakultas Adab Dan Humaniora Universitas Islam Negeri Alauddin Makasar, 2017. Hal. 1-2

${ }^{3}$ Yulia Nurendah, Analisis Pengaruh Kualitas Pelayanan... Hal. 93-94.

${ }^{4}$ Andi Pandita, Pengaruh Pelayanan Terhadap Kepuasan... Hal. 4. 
perangkat komunikasi seluler, media online, online games dan teknologi web. Belum lagi kemunculan aplikasi social networking seperti Facebook, Twitter, MySpace, Blogs, yang membuat penggunanya staying connected dengan berbagai perangkat komunikasi seperti Blackberry, IPhone, IPad, PC Tablet, dan sebagainya. Bagi kalangan anak muda, memiliki perangkat komunikasi seperti di atas lebih banyak sebagai bagian dari life style' dan banyak digunakan hanya untuk merepresentasikan dirinya, meskipun fitur-fitur dalam perangkat komunikasi tersebut masih bisa dieksplorasi lebih dalam dengan fitur beragam. Generasi seperti ini sudah menjadi pengguna perpustakaan. ${ }^{5}$

Pakar pendidikan Mark Prensky (2001) mengemukakan ada dua generasi yaitu digital natives dan digital immigrants.Digital nativesmerupakan generasi yang lahir pada era digital, sedangkan digital immigrants adalah generasi yang lahir sebelum era digital tetapi kemudian tertarik, lalu mengadopsi hal baru dari teknologi tersebut. Generasi digital nativeslebih banyak mengisi kehidupan dengan penggunaan komputer, video games, digital music players, video cams, cell phone dan berbagai macam perangkat permainan yang diproduksi di abad digital. Generasi digital nativessudah terkondisikan dengan lingkungan seperti itu dan mengganggap teknologi digital sebagai bagian yang tidak terpisahkan dari kehidupannya. Rata-rata generasi digital nativesketika lahir sudah berada dalam lingkungan teknologi digital. Pengguna perpustakaanpun tersebar dalam generasi digital natives dan digital immigrants dan diperkirakan dalam lima hingga sepuluh tahun yang akan datang pengguna perpustakaan perguruan tinggi dominan diisi oleh generasi digital natives. ${ }^{6}$

Pengguna potensial perpustakaan pada saat ini adalah mereka yang dikenal sebagai "net generation”. Salah satu karakteristik

${ }^{5}$ Riana Mardina, "Potensi Digital Nativies Dalam Pesentasi Literasi Informasi Multimedia Berbasis Web di Perguruan Tinggi", dalam Jurnal Pustakawan Indonesia Volume 11 No. 1. Hal. 5.

${ }^{6}$ Riana Mardina, Potensi Digital Nativies.... Hal. 5. 
netgeneration yang paling menonjol adalah mereka sudah terbiasa dengan teknologi informasi sehingga memiliki kemampuan yang memadai dalam memanfaatkannya untuk memenuhi kebutuhan informasi yang dibutuhkannya.Dengan kemampuan yang dimiliki, netgeneration lebih memilih menggunakan media internet untuk mencari informasi yang mereka butuhkan dibandingkan mencarinya di perpustakaan.Di sinilah tantangan bagi para pustakawan di era digital untuk memberikan pelayanan yang baik bagi pemustakanya, khususnya net generation tersebut. ${ }^{7}$

Berdasarkan penjelasan diatas, rumusan masalah artikel ini adalah bagaimana upaya peningkatan kualitas pelayanan terhadap gerenasi digital Native?

\section{B. Pembahasan}

\section{Pengertian kualitas pelayanan}

Istilah "kualitas" mengandung banyak definisi dan makna. Hal ini sangat tergantung dari siapa yg mendefinisikan, dalam bidang apa kata kualitas digunakan, dari sudut pandang permasalahan apa yang dibahas, dan untuk keperluan apa mempergunakannya. Kualitas perpustakaan lebih menekankan pada aspek kepuasan dengan fokus utamanya yaitu keperluan atau kebutuhan pemustaka (users utility).

Dalam ISO 8402 dan SNI (Standar Nasional Indonesia), kualitas adalah keseluruhan ciri dan karakteristik produk atau jasa yang kemampuannya dapat memuaskan kebutuhan, baik yang dinyatakan secara tegas maupun tersamar.Istilah kebutuhan diartikan sebagai spesifikasi yang tercantum dalam kontrak maupun kriteria-kriteria yang harus didefinisikan terlebih dahulu. Pelayanan merupakan proses pemenuhan kebutuhan melalui aktivitas orang lain secara langsung. Sedangkan, pengertian pelayanan dalam Kamus Umum Bahasa Indonesia, pelayanan adalah menolong

${ }^{7}$ Dian Hapsari, “Tantangan Dan Kompetensi Pustakawan DiIEra Digital”, dalam Jurnal Pustaka Ilmiah,VOL. 1, No. 1 TAHUN 2015 , Hal. 55-56. 
menyediakan segala apa yang diperlukan orang lain seperti tamu atau pembeli. Menurut Kotler (1994), pelayanan adalah aktivitas atau hasil yang dapat ditawarkan oleh sebuah lembaga kepada pihak lain yang biasanya tidak kasat mata, dan hasilnya tidak dapat dimiliki oleh pihak lain tersebut.

Hadipranata (1980) berpendapat bahwa, pelayanan adalah aktivitas tambahan di luar tugas pokok (job description) yang diberikan kepada konsumen-pelanggan, nasabah, dan sebagainyaserta dirasakan baik sebagai penghargaan maupun penghormatan. Bahkan citra suatu perpustakaan ditentukan oleh hasil dari bagaimana usaha pustakawan tersebut dalam memberikan layanan yang mampu memuaskan pemustakanya. Dalam filosofi tentang kualitas, menurut Tjiptono ${ }^{8}$, ada 4 guru kualitas yang mendefinisikan tentang kualitas, yaitu:

a) Josep M. Juran, mendefinisikan kualitas sebagai kecocokan untuk pemakaian (fitness for use). Jadi definisi ini menekankan orientasi pada pemenuhan harapan pelanggan.

b) Philip P. Crosby, merupakan pentingnya melibatkan setiap orang dalam organisasi pada proses, yaitu dengan jalan menekankan kesesuaian individual terhadap persyaratan atau tuntutan. Pendekatan Crosby merupakan proses top-down.

c) W. Edwards Deming, yang dikenal dengan "bapak gerakan pengendalian mutu" melalui strateginya didasarkan pada alat-alat statistik yang cenderung bersifat bottom-up. Penekanan utamanya adalah perbaikan dan pengukuran kualitas secara terusmenerus.

d) Taguchi, bahwa strateginya difokuskan pada loss function. Filosofi Taguchi didasarkan pada premis bahwa

${ }^{8}$ Tjiptono, Fandi. Prinsip-Prinsip Total Quality Service (TQS). Yogyakarta: Andi, 2004, hal. 11. 
biaya dapat diturunkan dengan memperbaiki kualitas, sehingga kualitas tersebut otomatis dapat diperbaiki dengan cara mengurangi variasi dalam produk dan proses.

Berdasarkan keempat pendapat dari guru dalam bidang kualitas tersebut, ternyata mempunyai kesamaan pesan dalam mendefinisikan kualitas.Kesamaanya adalah bahwa untuk memenuhi suatu kualitas dibutuhkan fokus pada pelanggan dan kerjasama semua bagian serta pengembangan yang terus menerus dan bekelanjutan.Dengan demikian benar kiranya jika perpustakaan ingin memberikan layanan yang berkualitas harus fokus atau berorientasi kepadapemustakanya.

\section{Generasi Digital Natives}

Impak teknologi informasi tidak hanya memunculkan pada kepemilikan perangkat komunikasi tetapi berdampak pada kebiasaan seseorang dalam mengakses informasi. Perpustakaan perguruan tinggi memiliki peran penting dalam memberdayakan koleksi dan pengguna seperti yang dikemukakan Hawisher yang dikutip Avarez (2009) bahwa "Today, if students cannot write to the screen - if they cannot design, author, analyze, and interpret material on the Web and in other digital environments - they may be incapable of functioning effectively as literate citizens in a growing number of social spheres". Mahasiswa sebagai pengguna perpustakaan muncul dalam pembagian generasi berbeda dan ini berdampak pula dengan penyediaan dan layanan perpustakaan. ${ }^{9}$

Generasi digital nativesmengganggap perangkat komunikasi sebagai bagian integral dari kehidupannya. Sedangkan orang-orang yang tidak lahir pada abad digital tetapi mengadopsi teknologi baru dianggap sebagai digital immigrants, karena ada proses adaptasi pada lingkungan dengan mengadopsi teknologi. Seorang individu yang lahir pada abad digital, tumbuh dan memperoleh pendidikan

\footnotetext{
${ }^{9}$ Riana Mardina, Potensi Digital Nativies... Hal. 6-7.
} 
pada tingkat sekolah dasar dengan perangkat komputer, individu tersebut dianggap sebagai generasi digital natives.Mulai dari pendidikan dasar sudah dihadapkan dengan penggunaan komputer, seperti, kuiz interaktif online, video games, handphone, internet, e-mail dan sebagainya.Sedangkan guru dianggap sebagai generasi digital immigrantsyang bisa saja keterampilan literasi komputer didapatkan pada masa kuliah atau memasuki dunia kerja.

Ku \& Soulier, 2009; Wilson (2004) yang dikutip Li et al., (2007) menyebutkan karakteristik digital natives sebagai orang yang 'opportunistic' dan 'omnivorous' yang menikmati sesuatu dalam lingkungan yang serba online (ingin mendapatkan informasi dengan cepat); menyukai kolaborasi dari satu orang ke orang lain (secara berjejaring); multitasking; menyukai proses kerja secara pararel; menyukai sesuatu yang berbentuk gambar interaktif dibanding dengan teks; menyukai bekerja sebagai suatu 'games'; mengharapkan suatu penghargaan, puas dengan sesuatu yang serba instan; akses secara random (hypertext). Lingkungan hypertext muncul seiring perkembangan internet sehingga berdampak pada cara yang berbeda dalam menggunakan informasi. Internet memfasilitasi perbedaan mengakses informasi bagi seorang individu dengan informasi sama tetapi dengan proses berbeda.

Braston (2006); Prensky (2001) menyebutkan kesenangan bermain games dari generasi digital natives memunculkan konsep 'gaming is learning tool' dan bisa digabungkan dengan pengetahuan dan informasi dan menarik bagi pendidik.Konsep ini sudah banyak diadopsi oleh perusahaan yan mengeluarkan permainan pendidikan interaktif (edutainment). Pendek kata generasi digital nativesselalu berinteraksi dan terhubung dengan internet sepanjang waktu. ${ }^{10}$

\section{Dimensi Kualitas Pelayanan}

Menurut Parasuraman dalam Lupiyoadi ${ }^{11}$, terdapat lima dimensi kualitas pelayanan sebagai berikut:

${ }^{10}$ Riana Mardina, Poetnsi Digital Nativies... Hal. 7.

${ }^{11}$ Lupiyoadi, Rambat. (2001). ManajemenPemasaran Jasa Teori dan Praktek. Jakarta: Salemba Empat, hal. 149. 
a. Tangibles atau bukti fisik, yaitu kemampuan suatu organisasi dalam menunjukkan eksistensinya kepada pihak eksternal. Penampilan dan kemampuan sarana dan prasarana fisik organisasi dan keadaan lingkungan sekitarnya adalah bukti nyata dari pelayanan yang diberikan oleh pemberi jasa.Ini meliputi fasilitas fisik (gedung), perlengkapan dan peralatan yang dipergunakan (teknologi), serta penampilan pegawainya.

b. Reliability atau keandalan, yaitu kemampuan organisasi (perusahaan) untuk memberikan pelayanan sesuai yang dijanjikan secara akurat dan terpercaya. Kinerja harus disesuaikan untuk pelanggan, seperti ketepatan waktu, pelayanan yang sama untuk semua pelanggan tanpa kesalahan, sikap simpatik.

c. Responsiveness atau ketanggapan, yaitu kemauan untuk membantu dan memberikan pelayanan yang cepat dan tepat kepada pelanggan, dengan penyampaian informasi yang jelas. Membiarkan konsumen menungu tanpa aanya suatu alasan yang jelas menyebabkan persepsi yang negatif dalam kualitas pelayanan.

d. Assurance atau jaminan dan kepastian, yaitu pengetahuan, kesopansantunan dan kemampuan pegawai untuk menumbuhkan rasa percaya para pelanggan perusahaan (organisasi). Dimana jaminan ini terdiri dari beberapa komponen; komunikasi, kredibilitas, keamanan, kompetensi dan sopan santun.

e. Empathy, yaitu memberikan perhatian yang tulus dan bersifat indiviual atau bersifat pribadi yang diberikan kepada para pelanggan dengan berupaya memahami keinginan konsumen. Suatu perusahaan (organisasi) diharapkan memiliki pengertian dan pengetahuan tentang pelanggan, memahami kebutuhan pelanggan secara spesifik, serta memiliki waktu pengoperasian yang nyaman bagi pelanggan. 


\section{Karakteristik Layanan Yang Berkualitas}

Menurut Rahayuningsih ${ }^{12}$ (2007) memaparkan karakteristik layanan pemustaka yang berkualitas dapat dilihat dari segi :

a. Koleksi

1) Kuantitas, berkaitan dengan banyaknya jumlah koleksi yang dimiliki oleh perpustakaan

2) Kualitas, berkaitan dengan mutu, kemutakhiran, kelengkapan koleksi.

b. Fasilitas

1) Kelengkapan, menyangkut lingkup layanan dan ketersediaan sarana pendukung serta layanan pelengkap lainnya.

2) Kenyamanan memperoleh layanan, berkaitan dengan lokasi, ruangan, petunjuk, ketersediaan informasi, kebersihan dan lain-lain.

c. Sumber daya manusia

1) Kesopanan dan keramahan petugas dalam memberi layanan, terutama bagi petugas yang berinteraksi langsung dengan pengguna.

2) Tanggung jawab dalam melayani pengguna perpustakaan.

3) Empati, wajar dan adil dalam memecahkan masalah dan menangani keluhan pengguna.

\section{Analisis Meningkatkan Kualitas Pelayanan Perpustakaan Terhadap Generasi Digital Native}

Pada analisis ini akan dijelaskan secara detail dan menyeluruh tetapi tetap berpedoman pada aspek kualitas pelayanan yang telah disampaikan oleh Lupiyoadi dan Rahyanungsih, yaitu : Tangibles, Reliability, Responsiveness, Assuranc, Empathy,Koleksi, Fasilitas, Sumber daya manusia.

a. Dimensi Tangible dan Fasilitas

Paradigma pelayanan saat ini tentunya harus dirubah mengingat bahwa yang dilayani adalah generasidigital 2007.Hal. 18.

${ }^{12}$ Rahayuningsih.Pengelolaan Perpustakaan. Yogyakarta: Graha Ilmu, 
natives,selain fisik gedung yang memadai harus ada perlatan dan fasilitas yang dibutuhkan oleh generasi digital natives, yaitu koneksi internet dan computer. Kalau dahulu perpustakaan cukup menyediakan gedung dan koleksi buku saja.Sekarang hal itu terasa kurang bagi generasi digital natives.

Hal tersebut seperti yang telah disampikan oleh Marc Prensky dalam Amirul Ulum ${ }^{13}$. Tidak dapat dipungkiri bahwa hampir semua mahasiswa yang ada pada saat ini adalah generasi yang lahir pada era teknologi informasi ataupun era digital. Marc Prensky menyebutkan bahwa mereka yang lahir pada era digital menghabiskan waktu mereka dan tinggal di lingkungan yang dikelilingi oleh computer, internet, video games, digital music player, video camera, tellepon sellular, dan berbagai macam mainan serta peralatan yang serba digital. Generasi tersebut menjadi generasi yang berada dalam lingkungan digital (D(Digital)-gen). sehingga tidaklah salah jika mereka disebut sebagai Digital Natives, dimana mereka adalah "nativespeakers" dari bahasa digital pada perangkat computer, jaringan internet, dan video games.

Digital Natives telah terbiasa dengan akses informasi berbasis web, selalu terkoneksi, dan membuat kelompok dalam dunia maya. Mereka memanfaatkan internet sebagai sumber informasi primer berdasarkan pengalaman.Namun sedikit dari mereka yang mengetahui bagaimana informasi tersebut dihasilkan, dikelompokkan dan disebarluaskan. Hal ini terlihat dari mereka dapatkan ketika melakukan penelusuran informasi melalui internet.

b. Reliability (kehandalan) dan Sumberdaya manusia

Perpustakaan harus memiliki pustakawan yang berkompetensi di bidang kepustakawanan, serta didukung dengan teknologi informasi mengingat yang dihadapi adalah

${ }^{13}$ Amirul Ulum, Membangun Pustakawan Modern, Yogyakarta : Azyan Mitra Media, 2017. Hal. 169-170. 
mereka yang setiap hari sudah terbiasa dengan computer dan internet.Selain kedua hal tersebut pustakawan perlu dibekali dengan soft sklill untuk menghadapi generasi digital natives.

Hal Tersebut senada dengan yang disampaikan oleh Amirul Ulum ${ }^{14}$, bagi perpustakaan dan pustakawan tentu harus mengikuti perkembangan tersebut dengan terlebih dahulu mengetahui bergagai karakteristik mereka dalam pemanfaatan perpustakaan, perilaku penelusuran informasi yang diharapkan.Dengan demikian semua sumberdaya informasi yang tersedia di perpustakaan dapat dimanfaatkan secara maksimal oleh pemustaka.

Semua fasilitas yang disediakan oleh perpustakaan dapat memenuhi keinginan pemustaka karena mereka memiliki harapan yang sangat besar bahwa perpustakaan dapat menyediakan semua sumber informasi, dapat dihubungi setiap saat, dan memiliki berbagai kecanggihan teknologi dalam menyampaikan informasi.Perpustakaan dapat meningtegrasikan semua layanan yang dimiliki dengan jaringan infromasi yang tersedia di luar perpustakaan. Sehingga mereka berharap selalu menemukan informasi yang dicari.

c. Responsivenes (ketanggapan)

Pustakawan harus memiliki kepekaan terhadap layanan, pemustaka yang dating dan mencari informasi harus segera dilayani dan diberikan informasi yang lebih serta bervariasi menurut permintaannya. Hal ini akan menunjukkan bahwa pustakawan langsung tanggap akan kebutuhan pemustaka dan mencerminkan pustakawan yang ahli di bidang informasi. Informasi yang diberikan pustakawan dengan waktu yang lama akan berdampak citra yang buruk terhadap pustakawan.

${ }^{14}$ Amirul Ulum, Amirul Ulum, Pustakawan, dan Digital ... Hal. 170. 
Rifaudin ${ }^{15}$ mengatakan bahwa pustakawan harus bisa melakukan dua hal, yaitu :

1) Mengenali kebutuhan pemustaka

Seorang pustakawan harus jeli dalam melihat siapa pemustakanya dan apakah pemustaka tersebut butuh bantuan pustakawan atau tidak. Hal paling penting yang harus dilakukan pustakawan adalah mereka harus memberikan hak yang sama kepada pemustakanya. Di samping mengenali kebutuhan pelanggan atau pemustaka, pustakawan harus mengenali karakteristik pemustaka tersebut

2) Memenuhi kebutuhan pemustaka

Sebelum memberikan pelayanan kepada pelanggan (pemustaka), pustakawan harus mengetahui beberapa kebutuhan dasar pemustaka.Pustakawan harus mengetahui dan dapat memahami pemustaka dengan baik sebelum memberikan pelayanan, hal ini dilakukan agar pelayanan yang diberikan tidak menyimpang dari kebutuhan pemustaka.Pustakawan diharapkan cepat tanggap dalam merespon pertanyaan tentang informasi yang dibutuhkan oleh pemustaka, dapat memberikanpenelusuran informasi yang dibutuhkan dengan cepat dan tepat, mampu membedakan antara hal yang penting dan tidak penting tentang informasi.

\section{d. Assurance dan Koleksi}

Jaminan akankelengkapan dan ketersediaan koleksi merupakan daya tarik para pemustaka. Apa yang setiap pemustaka cari dan bisa didapatkan oleh pemustaka akan membuat puas bagi mereka. Sering kali kita melihat pemustaka kecewa karena infromasi yang mereka butuhkan

${ }^{15}$ Machsun Rifauddin, Keterampilan Sosial PustakawanDalam Memberikan Pelayanan Bermutu Di Perpustakaan, dalam Jurnal KHIZANAH AL-HIKMAH Vol. 5 No.1, Januari - Juni 2017. Hal. 109-110. 
tidak ditemukan. Padahal mereka sudah datang dari jauh dan mengorbakan waktu.

Menurut Nuning Kurniasih ${ }^{16}$ Digital Natives (Generasi Digital) cenderung untuk menerima informasi secara cepat dari berbagai sumber, seperti multi media dan menggunakan sumber-sumber hyperlink; bekerja secara serentak (multitasking) dengan proses berpikir yang pararel ; berinteraksi secara real-time serta menghasilkan konten. Setiap orang dapat menjadi produsen informasi.

Pada era ini perpustakaan tentunya harus menyediakan koleksi yang bermacam-macam bentuknya, tidak stagnan hanya koleksi buku saja. Melainkan harus disesuaikan dengan perkembangan zaman.Dengan adanya internet koleksikoleksi tersebut bisa diakses lewat mana saja dan kapan saja. Koleksi yang seharusnya ada perpustakaan saat ini yaitu :

1) Buku Elektronik atau e-book

E-book merupakan bentuk digital dari sebuah buku yang berisi informasi tertentu.E-book memiliki format penyajian yang runtut, baik bahasanya, tinggi kadar keilmuannya, dan luas pembahasannya. Kelebihan dari e-book antara lain kemudahan penelusuran dan membacanya, penghematan bahan kertas, dan kemudahan pengalihan teks. Menurut Wiji Suwarno ${ }^{17}$, e-book adalah versi elektronik dari buku. Jika buku pada umumnya terdiri dari kumpulan kertas yang berisi teks atau gambar, e-book berisi informasi digital yang juga dapat berwujud teks atau gambar. Sedangkan menurut Putut Laxman Pendit e-book adalah bentuk buku elektronik secara sederhana bias dilihat dalam bentuk

${ }^{16}$ Nuning Kurniasih, "Kualifikasi Pustakawan di Era Digital”, dalam Prosiding Semiloka Nasional Kepustakawanan Indonesia 2015 "Library Move on: Bangga Menjadi Profesional di Dunia Perpustakaan dan Informasi” UPI Bandung, 19-21 Agustus 2015. Hlm: 439-449

${ }^{17}$ Suwarno, Wiji. 2011. Dasar-dasar Ilmu Perpustakaan. Yogyakarta : Ar-Ruzz Media, hal. 74. 
teks yang tersaji dalam bentuk dokumen yang dibuat dengan wordprocessor, HTML, atau XML.

2) Kertas elektronik

Kertas elektronik ${ }^{18}$ (electronic paper atau epaper) adalah sebuah teknologi portabel yang tampilannya hampir sama seperti kertas biasa, namun dapat diakses ribuan kali. Berbeda seperti kertas biasa yang hanya bisa sekali ditulisi, kertas elektronik bisa menerima tulisan dan me-refreshnya berkali-kali.Kertas elektronik dianggap lebih nyaman untuk digunakan dibandingkan layar konvensional karena tampilan gambarnya yang lebih stabil, tidak perlu melakukan refresh secara konstan, dan distribusi sebaran yang lebih luas. Teknologi kertas elektronik (e-paper) digunakan untuk menjalankan aplikasi e-book dan electronicnewspaper. Perkembangan penggunaan e-paper khususnya di media koran online saat ini berkembang sangat pesat. Dengan tampilan informasi yang dikemas dalam e-paper serta disajikan secara online tentunya menambah daya tarik tersendiri.

3) E-Journal

Salah satu inovasi yang ada dalam perpustakaan digital di perguruan tinggi sebagai produk perkembangan teknologi informasi dan komunikasi adalah elektronik journal (e-journal). E-journal dalam studi komunikasi massa berfungsi sebagai media komunikasi yang menyampaikan pesan-pesan komunikasi kepada khalayak (massa).

E-journal dalam dunia pendidikan tinggi berfungsi sebagai media informasi dan komunikasi mengenai bahan, refensi, bahkan jurnal penelitian ilmiah yang

${ }^{18}$ Aan Prabowo, Heriyanto, Analisis Pemanfaatan Buku Eelektronik ( E-BOOK) Oleh Pemustaka Di Perpustakaan SMA Negeri 1 Semarang, dalam JURNAL ILMU PERPUSTAKAAN Volume 2, Nomor 2, Tahun 2013, hal. 115. Online dari http: http://ejournal-s1.undip.ac.id/index.php/jip 
dibutuhkan oleh civitas akademik.Keberadaan layanan e-journal di perguruan tinggi tentunya membantu civitas akademik dalam menunjang aktivitas akademiknya.Ejournal dengan segala kecepatan dan kelebihannya memungkinkan terjadi dialektika suatu ilmu pengetahuan yang cepat pula sehingga diharapkan pemutakhiran suatu ilmu pengetahuan semakin intensif. ${ }^{19}$

Penggunaan jurnal elektronik semakin banyak daripada jurnal tercetak karena memiliki banyak keunggulan.Jurnal elektronik atau e-journal yang sering kali sudah terbit terlebih dahulu sebelum jurnal tercetak.6 Pemanfaatan jurnal elektronik juga bisa menghemat waktu, biaya, dan tenaga.Mahasiswa dapat memanfaatkan jurnal elektronik tersebut dari mana saja dan kapan saja.Pustakawan juga tidak perlu mengindeks jurnal tersebut, karena sistem jurnal elektronik sudah menyediakan fasilitas pengindeksan. Fungsi utama dari jurnal tetap sama, yaitu mendaftar, menyebarkan, memeriksa ke sesama rekan ilmuan (peer review) dan melestarikan ilmu pengetahuan.8 Kehadiran jurnal elektronik diharapkan mampu menunjang penelitian serta proses pembelajaran sivitas akademika perguruan tinggi sebagai sumber referensi yang dapat diakses dengan mudah dan cepat. ${ }^{20}$

e. Emphaty

Perpustakaan harus memiliki pustakawan yang memiliki rasa emphaty yang tinggi karena yang dihadapi adalah bukan benda mati. Menghormati dan memerikan perhatian kepada pemustaka akan berdampak sangat luar

${ }^{19}$ Mustati," dan M. Najib HM, "Pemanfaatan E-Journal Dalam Memenuhi Kebutuhan Informasi Ilmiah DiKalangan Civitas Akademik Universitas Hasanuddin", dalam Jurnal Komunikasi KAREBA Vol. 2, No.1 Januari - Maret 2013, hal. 101-102 (100-109)

${ }^{20}$ Muhammad Azwar dan Rizka Amaliah, "Pemanfaatan Jurnal Elektronik Sebagai Sumber Referensi Dalam Penulisan Skripsi Di Institut Pertanian Bogor", dalam Jurnal Libraria, Vol. 5, No. 1, Juni 2017. Hal. 4 (1-24) 
biasa. Beberapa hal yang bisa dilakukan pustakawan dalam menghadapi generasi digital native adalah :

1) Menggunakan media komunikasi secara efektif. ${ }^{21}$ Pustakawan harus memiliki kemampuan dalam menggunakan media komunikasi secara efektif. Saat memberikan pelayanan kepada pemustaka menggunakan media komunikasi misalnya komputer pustakawan harus bertindak secara cepat dan tepat tanpa membuat pemustaka terlalu lama menunggu untuk mendapatkan pelayanan yang diinginkan. Dalam hal ini pustakawan dituntut untuk menguasai teknologi informasi secara efektif.

2) Komunikasi yang baik. ${ }^{22} \mathrm{Di}$ dalam perpustakaan sendiri komunikasi terlihat sebagai proses yang terus menerus, mempengaruhi setiap elemen dalam sebuah lembaga dan karena sifatnya yang terus menerus, maka komunikasi menjadi bersifat dinamis, bergantung pada tempat, waktu, dan kondisi di mana komunikasi itu berjalan. Peran pustakawan dalam berkomunikasi dengan pemustaka sangatlah vital.Seorang pustakawan diharapkan dapat menguasai tehnik komunikasi yang baik, dapat menimbulkan sikap saling pengertian dan saling menguntungkan antara kedua belah pihak baik pustakawan dan pemustaka.Kunci komunikasi yang efektif adalah mencoba mengerti dan melakukan tindakan yang bisa memberikan kepuasan pemustaka. Pustakawan dituntut untuk mengetahui, kemudian mempraktekkan berbagai macam dan bentuk komunikasi supaya perpustakaan yang dikelolahnya mampu memahami kebutuhan informasi yang dibutuhkan oleh penggunanya.Dalam berkmunikasi di social media pun harus sedemikian dan sopan, karena

${ }^{21}$ Machsun Rifauddin, "Ketarampilan Sosial Pustakawan Dalam Memberikan Pelayan ermutu Di Perpustakaan", dalam Jurnal KHIZANAH ALHIKMAH Vol. 5 No.1, Januari - Juni 2017. Hal. 109.

${ }^{22}$ Ibid, hlm. 108. 
tidak menutup kemungkinan antara pustakawan dan pemustaka telah menjalin pertemanan melalui akun social media.

\section{Simpulan}

Generasi Digital Natives, yaitu generasi muda yang lahir dan hidup pada era internet cenderung menggunakan dunia internet dalam kehidupan sehari-hari. Secara langsung generasi ini yang akan menjadi pemustaka di perpustakaan terutama di perguruan tinggi. Pola komunikasi pemustaka perpustakaan saat ini lebih banyak dipengaruhi oleh perkembangan teknologi komunikasi berbasis informasi yang berkembang pesat. Penggunaan telepon sellular, instant messaging, serta jejaring social menjadi media komunikasi utama bagi digital natives. Mereka sangat menguasai akan hal ini dan tentunya menuntut pustakawan mampu menyediakan akses berbasis teknologi komunikasi tersebut.

Selain fasiltas dan teknologi komunikasi, perpustakaan harus menyediakn koleksi yang sudah bisa diakses melalui internet, sehingga bisa dibaca kapan saja dan dimana saja, antara lain yaitu E-Book, E-Paper dan E-Journal.Utamanya adalah koleksi E-Journal. Karena E-journal adalah suatu bentuk digitalisasi ilmu pengetahuan yang memungkinkan pengguna mengakses secara mudah serta dengan manajemen kerja sama (berlangganan) suatu perpustakaan dengan perpustakaan lain, institusi atau penerbit e-journal lainnya, maka kebutuhan akan ilmu pengetahuan yang bervariatif dan terbaru (up date) akan terpenuhinya. Hal ini akan berimplikasi semakin canggih dan berkembangnya ilmu pengetahuan yang diterapkan, dikembangkan dan dihasilkan oleh perguruan tinggi tersebut. Bagi mahasiswa, suatu jurnal atau e-journal akan membantu atau berkontribusi dalam setiap tugas akademik hingga penelitiannya. 


\section{DAFTAR PUSTAKA}

Aan Prabowo, Heriyanto, ANALISIS PEMANFAATAN BUKU ELEKTRONIK ( E-BOOK ) OLEH PEMUSTAKA DI PERPUSTAKAAN SMA NEGERI 1 SEMARANG, dalam JURNAL ILMU PERPUSTAKAAN Volume 2, Nomor 2, Tahun 2013, 1-9 hlm. Online dari http: http://ejournal-s1. undip.ac.id/index.php/jip

Amirul Ulum, Membangun Pustakawan Modern, Yogyakarta : Azyan Mitra Media, 2017.

Andi Pandita, "Pengaruh Pelayanan Terhadap Kepuasan Pemustaka Di UPT Perpustakaan Universitas Negeri Makasar". Skripsi. Fakultas Adab Dan Humaniora Universitas Islam Negeri Alauddin Makasar, 2017. Hal. 1-2

Dian Hapsari, “Tantangan Dan Kompetensi Pustakawan DiIEra Digital", dalam Jurnal Pustaka Ilmiah, VOL. 1, No. 1 TAHUN 2015, 55-60 hlm.

Lupiyoadi, Rambat. (2001). ManajemenPemasaran Jasa Teori dan

Praktek. Jakarta: Salemba Empat, hal. 149.

Machsun Rifauddin, "Ketarampilan Sosial Pustakawan Dalam Memberikan Pelayan ermutu Di Perpustakaan", dalam Jurnal KHIZANAH AL-HIKMAH Vol. 5 No.1, Januari Juni 2017. 102-122 Hlm.

Muhammad Azwar dan Rizka Amaliah, "Pemanfaatan Jurnal Elektronik Sebagai Sumber Referensi Dalam Penulisan Skripsi Di Institut Pertanian Bogor", dalam Jurnal Libraria, Vol. 5, No. 1, Juni 2017. 1-24 hlm.

Mustati,, dan M. Najib HM, "Pemanfaatan E-Journal Dalam Memenuhi Kebutuhan Informasi Ilmiah Di Kalangan Civitas Akademik Universitas Hasanuddin", dalam Jurnal Komunikasi KAREBA Vol. 2, No.1 Januari - Maret 2013, 100-109 hlm. 
Nuning Kurniasih, "Kualifikasi Pustakawan di Era Digital”, dalam Prosiding Semiloka Nasional Kepustakawanan Indonesia 2015 "Library Move on: Bangga Menjadi Profesional di Dunia Perpustakaan dan Informasi" UPI Bandung, 19-21 Agustus 2015. Hlm: 439-449

Rahayuningsih.Pengelolaan Perpustakaan. Yogyakarta: Graha Ilmu, 2007. Hal. 18

Riana Mardina, "Poetnsi Digital Nativies Dalam Pesentasi Literasi Informasi Multimedia Berbasis Web di Perguruan Tinggi", dalam Jurnal Pustakawan Indonesia. Volume 11 No. 1.5$14 \mathrm{hlm}$.

Suwarno, Wiji. 2011. Dasar-dasar Ilmu Perpustakaan. Yogyakarta : Ar-Ruzz Media, hal. 74.

Tjiptono, Fandi. Prinsip-Prinsip Total Quality Service (TQS). Yogyakarta: Andi, 2004, hal. 11.

Yulia Nurendah, "Analisis Pengaruh Kualitas PelayananPerpustakaan Terhadap Kepuasan danHubungannya dengan Loyalitas Mahasiswa", JIMKES Jurnal Ilmiah Manajemen Kesatuan Vol. 1 No. 1, 2013. 93-112 hlm. 